\title{
Fiscaoeconomia
}

Journal Homepage: dergipark.gov.tr/fsecon

\section{Melez Rejimlerden Çıkışta Seçim İttifakları: 2019 Macaristan Yerel Seçimi Üzerine Bir İnceleme}

Electoral Coalitions To Exit From Hybrid Regimes: A Research on The Hungary 2019 Local Election

Mustafa Cem OĞUZ ${ }^{1}$

Article Info

Article History:

Date Submitted: 23.12 .2019

Date Accepted: 11.01.2020

Jel Classification

$D 70, D 72, P 16$

Keywords:

Hybrid Regimes,

Competitive Authoritarian

Regimes,

Local Elections,

Electoral Coalitions,

Fidesz,

Karacsony.
Abstract

The success of electoral coalition has long been acknowledged for the peaceful exit from hybrid regimes. According to this, the opposition that goes to alliance in the repressive regimes first makes the field of competition more fair and then ensures the democratization of the regime. Although democratization literature focuses on general elections, local elections have gained importance since 1990s with increasing importance of local governments. In this study, we will discuss the electoral coalitions in local elections and argue that the local elections won by this strategy are effective in the exit from hybrid regimes. We will try to prove this claim through the 2019 local elections in Hungary.

\section{Özet}

Melez rejimlerden barışçı çıkışta seçim ittifaklarının başarısı uzun zamandır kabul edilmektedir. Buna göre baskıcı rejimlerde ittifaka giden muhalefet önce rekabet alanını daha adil hale getirmekte, sonrasında da rejimin demokratikleşmesini sağlamaktadır. Demokratikleşme literatürü her ne kadar odağına genel seçimleri alıyor olsa da, 1990'lardan itibaren yerel yönetimlerin artan önemi ile yerel seçimler de önem kazanmaya başlamıştır. Biz bu çalışmamızda yerel seçimlerde uygulanan seçim ittifaklarını ele alacağız ve bu strateji ile kazanılan yerel seçimlerin de melez rejimlerden çıkışta etkili olduğunu savunacağız. Bu iddiamızı da Macaristan'ın 2019 yerel seçimleri üzerinden kanıtlamaya çalışacağız.

\footnotetext{
${ }^{1}$ Dr.Öğretim Üyesi, Niğde Ömer Halisdemir Üniversitesi, Kamu Yönetimi Bölümü. Email: oguzmustafacem@gmail.com
} 


\section{Giriş}

21.yy’ın üzerinde en fazla tartışılan siyasal temasının Melez Rejimler olduğu söylenebilir. $\mathrm{Bu}$ tip rejimlerin demokratikleşmesinin mümkün olup olmadığı ve mümkünse bunun nasıl kotarılacağ1 üzerine geniş bir literatür mevcuttur. Son dönemde yapılan karşılaştırmalı çalışmalarda, demokratikleşen melez rejimlerin büyük çoğunluğunda bu başarının "seçim ittifakına" giden muhalefet ile elde edildiği ortaya konmuştur. Seçim ittifakları sadece muhalefeti tek vücut haline getirmemektedir, seçmenlerin sandığa ve başarıya olan inancını artırıp, seçime katılımı da yükseltmektedir. Bunun ötesinde siyasal mücadele alanının daha rekabetçi hale gelmesini sağlamaktadır. Zira muhalefetin birlikteliği, otokratik iktidarın manipülasyon alanını sınırlamaktadır. Bu tip rejimlerde medya, sermaye çevreleri, güvenlik bürokrasisi ve yargı seçim ittifakı ile kazanma ihtimali yükselen muhalefetten dolayı iktidar ile aralarına belirli bir mesafe koyma eğilimine girmektedirler. Bununla birlikte ilgili literatür seçim ittifakının mutlaka iktidarın el değişimine neden olacağını da iddia etmemektedir. Ancak ittifaklar bahsedilen özelliklerinden dolayı "özgürleştirici seçim sonuçları” da verebilmektedir. Öyle ki, bu strateji ile iktidarın güç ve kontrol alanı daralırken, muhalefetin cesareti yükselmektedir. Bu da rekabet alanını daha eşitlikçi hale getirip, bir sonraki seçimin başarı şansını artırmaktadır.

Seçim ittifaklarını inceleyen literatür genellikle bu olguya "genel seçimler" üzerinden yaklaşmış ve “yerel seçimleri” pek dikkate almamıştır. Bu tutum, "demokratikleşme” literatürü ile de uyum içindedir. Zira baskıcı rejimlerden barışçı çıkışta nihai nokta genel seçimdir ve bu nedenle o momente odaklanılması olağandır. Ancak özellikle 1990'lardan itibaren yerel yönetimlerin güçlenmesi ile birlikte yerel siyaset de, demokratikleşme tartışmalarına dahil olmuştur. Bu nedenle biz çalışmamızda yerel seçimlerdeki seçim ittifaklarına odaklanacağız ve inceleme nesnesi olarak da Macaristan' in 2019 yerel seçimine bakacağız. 2010 yılından itibaren popülist-otokrat Fidesz Partisi tarafından yönetilen ülkede, demokrasinin genel durumu yıllar içinde kötüleşti ve rekabetçi otoriteryan bir rejim ortaya çıktı. Muhalefet 2014 seçimlerinden bu güne kadar seçim ittifaklarına başvurmasına rağmen istenilen sonucu bir türlü elde edemedi. Ancak 2019 yılında yapılan yerel seçimlerde, ittifak stratejisi ilk defa işe yaradı ve muhalefet başta başkent Budapeşte olmak üzere birçok şehrin yönetimini kazanmayı başardı. Biz çalışmamızda muhalefetin yıllar içindeki içindeki ittifak denemelerini ele alacağız ve sonrasında da yerel seçimdeki ittifak ve kampanya sürecini irdeleyeceğiz. Buradaki iddiamız 
şudur ki, seçim ittifakı ile elde edilen yereldeki bu zafer "özgürleştirici seçim sonuçlarına" gebedir ve yakın vadede önce siyasal alanın rekabetçi bir hale kavuşması, sonrasında da bu rekabetçi otoriter rejimden çıkılması gayet olasıdır.

\section{Rekabetçi Otoriter Rejimlerden Çıkışta Seçim İttifakları}

Sovyetler Birliği'nin yıkılışı ile birlikte totaliter rejimlerin ve bu rejimlere karşı ya da bu rejimleri bahane ederek varlığını sürdüren otoriter rejimlerin sonunun geldiğine inanılmıştı. Demokratikleşme dalgası kısa zamanda tüm dünyayı sarmış ve demokrasi siyasal rejimlerin temel formu olarak kabul edilir olmuştu. Öyle ki, tarihin sonunun geldiği iddiaları dile getirilmiş ve bu noktadan geriye dönüşün mümkün olmadığı iddiaları öne sürülmüştü. Ancak 2000'li yılların başından itibaren bu iyimser kehanetlerin üzerine şüphenin gölgesi düşer oldu. Renkli Devrimler'i kendi ikballeri için bir tehdit olarak yorumlayan birçok eski totaliter ve otoriter rejim hızla demokratikleşme dalgasından uzaklaştılar. Bu geri dönüş kısa zamanda yeni bir ters dalga haline geldi ve otoriterleşme küreselleşti (Diamond, Plattener \& Walker, 2016). Latin Amerika'dan Doğu Avrupa'ya ve Ortadoğu'ya kadar birçok farklı bölgede oturmamış birçok demokrasi özellikle de popülist bir liderin iktidara gelmesiyle birlikte demokrasi rotasından ayrıldılar. Ancak bu rejimler tam anlamıyla geleneksel otoriter rejimlere de dönüşmediler ve demokratik rejimler ile otoriter rejimler arasındaki bir "gri bölgeye" hapsoldular (Carothers, 2002). Gri bölgedeki bu rejimler birbirlerinden oldukça farklılaşabilmektedir; bazıları demokratik rejimlerin kusurlu formlarıyken, diğerleri otoriter rejimlerin görece zayıf formlarıdırlar. $\mathrm{Bu}$ nedenle de farklı farklı adlandırmalar ile anılabilmektedirler ama bu geniş kategori genellikle "melez rejimler" olarak adlandırılmaktadır (Diamond, 2002; Bogaards, 2009). Melez rejimlerin en s1k görülen ve üzerinde en yoğun tartışmaların yapıldı̆̆ 1 formu ise Levitsky ve Way'in (2010) popülerleştirdiği "Rekabetçi Otoriter Rejimler"dir.

Rekabetçi Otoriter rejimler kağıt üzerinde rekabetçi rejimlerdir ve fakat iktidarı elinde tutan güç avantajın kendi elinde kalmasını sağlayacak şekilde siyasal alanı sürekli yeniden düzenlemektedir. Bu noktada anahtar kelime de "eşitsiz oyun alanı”dır. İktidar, rakiplerin oyun alanına girişlerine izin vermekle birlikte bu oyun alanını kendi lehine, adil olmayan bir şekilde daima yapılandırır. Levitsky ve Way’e (2010: 5) göre bu rejimler, muhalefete demokratik imkanlar sunması açısından rekabetçilerken, rekabet alanını iktidar lehine orantısız bir şekilde 
düzenlemiş olmaları açısından demokratik değildirler. Eşitsiz oyun alanı ise üç cepheden kurulmaktadır: mali kaynaklar, medya ve hukuk. Muhalefet bu rejimlerde seçim kampanyalarını finanse edecek mali kaynaklara erişememektedir, zira hükümet finansal çevreler üzerinde kurduğu baskı ile muhalefeti bu kaynaklardan mahrum bırakmaktadır. Aynı şekilde medyaya erişimleri de son derece sınırlandırılmıştır. Bu örneklerde medya, ya tamamen iktidarın kontrolü altındadır ya da muhalefet ile yakınlaşamayacak kadar sindirilmiştir. $\mathrm{Bu}$ nedenle de muhalefet medya üzerinden kamuoyuna kendisini anlatamamakta ve de iktidarın güdümündeki hakim medya tarafindan marjinalize edilmektedir. Rekabet alanını eşitsiz kılan bir diğer etken de hukuktur. Melez rejimlerde yargı erki, hükümetin kontrolü altında bulunmaktadır ve bunun doğrudan sonucu olarak da yürütmenin üzerinde bir yargı denetimi yoktur. İkinci olarak ise bu rejimlerde yargı tüm dikkatini muhalefet üzerinde toplamış ve onu cendere altına almıştır. Dolayısıyla muhalefet adalete erişemediği gibi sürekli kovuşturmaya ulaşmakta ve böylece hükümet ile adil bir rekabete girememektedir (Levitsky \& Way, 2010: $10,12)$.

Eşitsiz oyun alanının haricinde bu rejimler, seçimler ve temel hak ve hürriyetler konularında da liberal demokrasilerden ayrışmaktadır. Zira bu ülkelerde seçimlerin sonucu belirsiz olmakla birlikte iktidar çok güçlü manipülasyon araçlarına sahiptir ve seçimlere, rakiplerine karşı büyük bir avantajla girmektedir. Temek hak ve hürriyetler ise reddedilmemekte ve kağıt üzerinde saygı gösterilmekle birlikte, iktidar tarafından sürekli istismar edilmektedir. Ancak seçimler ve temel haklar konusundaki bu istismarlar karşısında ses çıkaran, tepki gösteren ve tam anlamıyla susturulamayan örgütlü bir muhalefet de mevcuttur (Levitsky \& Way, 2010: 7-9).

Yazarlar rekabetçi otoriter rejimlerin, demokratikleşme olasılığının mevcut olduğunu dile getirmekle birlikte bunun daha çok Batılı demokrasilerin etkisi ile mümkün olduğunu belirtmektedirler. Buna göre bu tip rejimler Batı ile hukuki, kültürel, ekonomik bağlantılara sahiplerse ya da Batı'nın finansal yardımlarına tabilerse daha yüksek bir oranda demokratikleşme imkanına sahiptirler. Ancak son dönemde "rekabetçi otoriter rejimler" üzerine yapılan çalışmalar Batı'ya olan yakınlığın, demokratikleşme getirmediği hatta Batı'nın kendi hegemonik alanındaki ülkelerin dahi demokrasiden uzaklaşmalarına mani olamadığını göstermişlerdir (Bozoki \& Hegedus, 2018). Yine bu alanda yapılan birçok çalışmada, rekabetçi otoriter rejimlerden çıkış başarısı gösteren ülkelerde iç dinamiklerin daha etkili olduğu iddia edilmiştir. İç dinamiklerin en başında ise "seçim ittifakları" gelmektedir. Buna göre muhalefetin 
seçim ittifakına gittiği bu tip rejimlerde ya iktidar el değiştirmekte, ya da "özgürleştirici seçim sonuçları" elde edilmektedir (Van de Walle, 2006; Howard ve Roessler, 2006; Bunce ve Wolchik, 2010: 61; Donno, 2013). Howard ve Roessler (2006: 371), seçim ittifaklarının neden başarı getirdiğini şu şekilde özetlemektedirler: Öncelikle seçim ittifakları, iktidarın böl ve yönet stratejisini uygulamasına mani olmaktadır; ikinci olarak bürokrasinin ve medyanın gözünde seçimde iktidarın manipülasyonuna dahil olma maliyetini artırmaktadır; üçüncü olarak ise umutsuz seçmenleri "değişime" inandırarak, sandığa gitmelerini teşvik etmektedir.

Seçim ittifaklarının en başarılı örnekleri 2000 yılında Sırbistan, Hırvatistan ve Gana'dan gelmiştir, 2015 yılında ise Malezya'da muhalefet ittifaka giderek, 42 yıldır iktidarı elinde tutan Barison Nasional'i devirmiştir. Seçim ittifakları her zaman iktidarın el değişimine neden olmasa da, muhalefet adına "özgürleştirici seçim sonuçlarına” da vesile olabilmektedir. Ulusal ve yerel seçimlerde ittifaklarla elde edilen kısmi başarılar, muhalefet adına bir kaldıraç etkisi sunabilmektedir. Öyle ki, yerel seçimlerdeki başarıların, ulusal siyaseti de dönüştürdüğü ve yereldeki kazanımların iktidar olma yolunda önemli bir firsat sunduğu da söylenmektedir (Fox, 1994). Bu nedenle seçim ittifaklarının yerel seçimlerde elde ettiği başarıların da demokratikleşme yolunda önemli bir etkide bulunacağı iddia edilebilir.

\section{Fidesz'in Yükselişi ve Macaristan'ın Dönüşümü}

Post-komünist ülkelerden biri olan Macaristan bu lig içerisinde özellikle 2000lerin ortalarına kadar demokratikleşme yarışının öncülerinden biri olarak görülüyordu. Ülkede istikrarlı hükümetler ve sağlıklı işleyen bir seçim sistemi vardı. Ayrıca bölgede uluslararası sermayenin de, en yoğun ilgi gösterdiği ülkelerden biriydi. Bu sağlıklı yapısı ile ülke 2004 yılında AB üyeliğini de elde etti. Öyle ki, bu döneminde Macaristan'ın artık bir "geçiş” ülkesi değil, demokrasinin “pekişmiş” olduğu bir ülke yorumları yapılır olmuştu (Magyar, 2016: XV). Ancak 2008 ekonomik krizinden olumsuz etkilenen ülke hılı bir türbülansa girdi ve fiili anlamda rejimini dönüştüren 2010 seçimini yaptı. Bu seçim ile sekiz yıldır ülkeyi yönetmekte olan Macar Sosyalist Partisi (MSZP) yerini milliyetçi-populist Fidesz ve müttefiki KDNP'ye birakt1.

Fidesz bu seçimlerde biraz da seçim sisteminin zaafları ile aldığ $\% 52$ oy karşılığında parlamentonun \%68'ini elde etti. $\mathrm{Bu} 2 / 3$ çoğunluk iktidar partisinin tek başına anayasa değişikliği yapmasına imkan veriyordu ve Fidesz bu fırsatı değerlendirerek ivedi bir şekilde 
yeni bir anayasa yapt1. 2012 yılında yürürlüğe giren ve tamamen Fidesz'e ait olan bu anayasa ile kuvvetler ayrılığı büyük ölçüde tahrip edildi; parlamentonun yetkileri azaltıld1, yarg1 bağımsızlığ 1 zayıflatıldı ve medya üzerindeki siyasi baskı artırıldı (Buzogany, 2017: 1312). 2014 yllındaki seçimlere, seçim sistemini ve seçim bölgelerini değiştirerek giden Fidesz, oy oranı yedi puan düşmesine rağmen parlamentodaki koltuk yüzdesini artırmayı başardı ve anayasa değişikliği yapabilme çoğunluğunu korudu. 2015 yılında Freedom House da, ülkenin "pekişmiş demokrasi”" olan durumunu "yarı pekişmiş demokrasi”" olarak güncelledi. 2018 y1lında ise yine Freedom House, Macaristan'ın “demokrasiye geçen ülkeler” arasında en dramatik düşüşü yaşayan ülke olduğunu iddia etti.

Fidesz bu süre zarfinda yaptığı yasal düzenlemeler ve siyasi hamleler ile ülkeyi rekabetçi otoriteryan bir güzergâha soktu. Bu dönüşüm medya, sermaye ve hukuk alanında çok net bir şekilde gözlemlendi (Kreko \& Enyedi, 2018). Orban iktidara gelir gelmez yeni bir medya yasasını meclisten geçirdi. Bu düzenleme ile Medya Konseyi’ne bağlı "Ulusal Medya ve Telekomünikasyon Kurumu" ihdas edildi. Fidesz'in mutlak kontrolü altında olan Medya Konseyi doğal olarak bu kurumun da Fidesz yanlısı bir şekilde kurumsallaşmasını sağladı. Zira ikisinin de başkanı aynı kişiydi ve doğrudan Orban tarafından atanıyordu. Frekans dağıtımından sorumlu olan kurum ilk 18 ayında muhalefete frekans vermediği gibi frekans yenileme taleplerine de olumlu karşılık vermedi. En büyük ticari frekansı ise Ekonomi Bakanı'nın eski iş ortağına verdi (Bajomi-Lazar, 2013: 82). Medyayı denetleme yetkisine de sahip olan bu kurum muhalif basın kuruluşlarını cezalar ile bastırmaya da yöneldi. Düzenleme ile ayrıca kamu yayıncı kurumlarının hepsi bir çatı altında toplandı ve yeni oluşturulan bir üst yönetime bağlandı. Üst yönetim ise hızlı bir kadrolaşmaya giderek eski çalışanlardan 570 kişiyi işten çıkardı ve yerlerine partili kişileri istihdam etti. Macaristan Devlet Televizyonu (MTV) bu değişiklikten sonra muhalefete ayırdığı süreyi dramatik bir şekilde düşürdü ve iktidar koalisyonu hakkındaki haberler toplam haberlerin \%83'ünü oluşturur hale geldi. Devlet radyosu MR da, haber bültenlerinde muhalefete ayırdığ 1 süreyi \%19'lara kadar düşürdü (Bajomi-Lazar, 2013: 83-84). Fidesz ayrıca klientalistik ekonomi yönetimi sayesinde özel medya kuruluşlarını da kontrol altına almayı başarmıştır. 2016 tarihi itibariyle Orban'a yakın iş adamları kamu bankalarından aldıkları krediler ile medyanın tamamına yakınını ele geçirmişlerdir (Bajomi-Lazar, 2017: 167). Fidesz ayrıca kamu reklamlarını da bu medya organlarına vererek onların sadakatini canlı tutmayı başarmıştır (Batorfy \& Urban, 2019). Böylece hem kamu kaynaklarını kendi taraftarlarının kullanımına sunmuş hem de muhalefetin 
medyaya erişimini sınırlandırmıştır. Medyanın bu durumu ülkenin basın özgürlüğü skorlarına da yansımıştır. Freedom House raporlarına göre 2009'da özgür bir basına sahip olan ülke 2011 'den bugüne kadar kısmi özgür olarak derecelendirilmiştir².

Fidesz yargı alanında da birçok dramatik değişiklik yapmıştır. 2010 yılında üçte iki çoğunluk ile iktidara gelince önce anayasada ona yakın değişiklik yaptı. Bu değişiklikler neticesinde anayasa mahkemesine (AYM) aday gösterme hakkını büyük ölçüde kendi üzerine aldı, ayrıca mahkemenin vergi ve bütçe ile ilgili konularda denetim yetkisini ortadan kaldırdı. Fakat bu değişiklikler kamuoyunda tepki çekince Fidesz bunun bir siyasi krize neden olduğunu iddia ederek anayasayı yeniden yapma kararı aldı. 2012 yılında yapılan bu yeni anayasa ile iktidar üzerindeki tüm yatay denetim kurumlarından kurtulmuş oldu. Yeni anayasanın temel felsefesi parlamentodaki çoğunluğun denetim kurumları ile sınırlandırılmadan, denetimsiz bir şekilde ülkeyi yönetebilmesi ve Fidesz'in öngörülmez bir süre boyunca iktidarda kalmasıydı (Landau, 2013: 209). Yeni anayasa ile AYM'deki koltuk sayısı artırıldı ve böylece Fidesz'e yeni üye atama imkanı sunuldu. Ayrıca hakimlerin özlük haklarından sorumlu, tamamen iktidarın kontrolünde olan yeni bir Ulusal Yargı Ofisi oluşturuldu. Sonrasında hakim ve savcıların emeklilik yaşı altmış ikiye indirilerek birçoğu emekliye sevk edildi. Emekli olanların yerlerine ise Ulusal Yargı Ofisi ivedi şekilde Fidesz taraftarlarını doldurdu. Eş zamanda Yüksek Seçim Kurulu da partinin kontrolü altına girdi (Landau, 2013: 210). İktidarın yaptı̆̆ bu yeni anayasa ve kurumsallaştırdığ 1 yargı sistemi hem Venedik Komisyonu, hem de AB tarafindan "hukuk devletini ihlal etmek"le eleştirildi. Ancak Fidesz bu değişikliklerinin her birinin AB üyesi ülkelerde de bir örneği olduğunu iddia ederek eleştirileri savurdu. Scheppele (2013: 561) Fidesz'in yaptığı anayasanın maddeler bazında kusurunun bulunmadığını fakat bir araya geldiklerinde hukuk devleti ve yargıç bağımsızlığını ilga ederek, otoriter bir rejime kapı açtığını iddia ederek ortaya çıkan bu devleti "Frankenstate" olarak adlandırdı. 2018 yılına gelindiğinde ise Fidesz yargı sisteminde bir yeniliğe daha gidip, yeni “idare mahkemeleri” kurdu. Bu değişiklik ile AYM'nin idari anlaşmazlıklardaki denetimi ilga edilirken, yerine adalet bakanın doğrudan kontrolü altındaki bu mahkemeler geçti. Öyle ki, Cas Mudde bu değişiklik ile birlikte Macaristan'ın tam anlamıla rekabetçi bir otoriter rejim haline geldiğini iddia edecekti. ${ }^{3}$

\footnotetext{
2 "Freedom of the Press 2017: Hungary Profile", https://freedomhouse.org/report/freedom-press/2017/hungary

3 "Hungary Creates New Court System, Cementing Leader's Control of Judiciary", https://www.nytimes.com/2018/12/12/world/europe/hungary-courts.html
} 
Macaristan'ın yolsuzluk karnesi hiçbir zaman çok iyi olmamıştır ama 2010'dan sonra sistemin tüm denetim kurumlarının ortadan kalkmasıyla birlikte yeni bir aşamaya girildiği söylenebilir. Uluslararası Yolsuzluk İndeksi'ne göre Macaristan 2016 tarihi itibariyle 28 AB ülkesi arasında 25. sırada yer almaktadır. Yolsuzluklar, ekonomideki rekabetçi yapıya da zarar vermiş ve ülke Dünya Bankası verilerine göre rekabetçi ekonomi sıralamasında 69. sıraya gerilemiştir. Yolsuzluğun artış1 ve rekabetçiliğin düşüşü en net bir şekilde kamu ihalelerinde görülür olmuştur. Aynı yıl yapılan kamu ihalelerinin \%99'u davet usulü yapılırken, \%36'sına ise tek bir teklif verilmiştir. Öyle ki, 2009-15 arasında kamu ihalelerinin daha az rekabetçi ve şeffaf olduğu, ihalelerde davet usulünün daha sık benimsendiği tespit edilmiştir. Bu tür usulsüzlükler AB fonlarının ülke içindeki dağıtımında da görülmüş ve Fidesz'e yakın olan iş adamlarının tüm bu süreç boyunca zenginleştiği ortaya çıkmıştır (Toth \& Hajdu, 2015: 6). Örneğin 2010-16 yılları arasındaki kamu ihalelerinin \%4,5'unu Orban'ın yakın arkadaşı Lorinc Meszaros almıştır. Orban'ın ekonomi üzerindeki denetimi o kadar belirgindir ki, yakın ilişki içinde olduğu Lagos Simicska 2013 yılında kamu ihalelerinin \%11'ini alırken, 2015'te araları açılınca bu oran \%0,1'e kadar gerilemiştir (Martin, 2017: 274). Fidesz'in rekabet dışı rant aktarım mekanizmaları ile kendisine yakın iş adamlarını zenginleştirmesi ve karşılığında ise hem onların sadakatini sağlaması hem de muhalefetin kaynaklara erişimini sınırlaması birçok gözlemci tarafindan tespit edilmiştir. Macaristan'ın bu durumunu "Mafya Devlet” (Magyar, 2016), “ahbap-çavuş kapitalizmi” (crony capitalism) (Toth \& Hajdu, 2015; Martin, 2017) ve "prebendal" (Rogers, 2019) olarak adlandıran gözlemciler de vardır. ${ }^{4}$ Buna göre Fidesz kendisine yakın iş adamlarını, doğrudan yardım, vergi muafiyeti, kredi imkanları ve denetimlerden bağışıklık ile korumaktadır. Ahbap-çavuş kapitalizmi bu nedenle sadece piyasanın işleyişini değil, siyasal alandaki rekabeti de bozmakta ve rekabetçi otoriter rejimin devamlılı̆̆ını sağlamaktadır (Martin, 2017: 275).

Fidesz bunların haricinde denetim organlarının tamamına kendi üyelerini yerleştirdi. Başsavcılık, Ombudsmanlık ve de Sayıştay başkanlığı böylece hükümeti kontrol eden kurumlar olmaktan çıkarıldı (Biro-Nagy, 2017). Seçim kanununda 2014 yılında değişikliğe gidilerek,

\footnotetext{
${ }^{4}$ Toht ve Hajdu (2018), yakın tarihli yaptıkları bir çalışmada ise Macaristan'ı, ahbap-çavuş kapitalizminin en radikal formu olarak tanımladıkları "Kleptokratik Devlet" olarak nitelendirmişlerdir. Bunun nedeni ise ahbapçavuş kapitalizminde, siyasi liderlerin kendilerine yakın iş adamlarına rekabete aykırı şekilde rant sunmalarına karşın, kleptokratik devlette siyasi liderlerin, kamu kaynaklarını iş adamlarına sunmayıp, kendi akrabalarına ve yakın çevresine dağıtmasıdır. Araştırmacılar Orban'ın etrafındaki iş adamı sayısının zamanla azalıp, dört kişilik bir gruba evrildiğini iddia etmektedirler. Bunlar çocukluk arkadaşı Meszaros, yakın dostu Istvan Garancsi, Damadı Istvan Tiborcz ve üniversiteden yurt arkadaşı Lajos Simicska.
} 
Fidesz'in 2/3 çoğunluğunu koruyabilmesi adına seçim bölgeleri yeniden şekillendirildi. Seçimi gözlemleyen AGİT bu seçimde parti ve devletin iç içe geçtiği, devlet medyasının imkanlarının hükümet lehine kullanıldığı tespitinden hareketle seçimin “özgür ve fakat rekabetçi” olmadığını $\operatorname{raporlad1}^{5}$. Bunların haricinde sivil toplum üzerinde de büyük bir baskı kuruldu. Özellikle Batı ile yakın ilişki içinde olan ve onların fonlarından faydalanan STK'lar ihanet ile suçlanarak baskıya uğradılar. Hedef tahtasının ortasına ise George Soros ve Orta Avrupa Üniversitesi oturtuldu. Victor Orban ise 2014 yılında demokrasinin bu gerileyişine sahip çıkmış ve amacının "illiberal bir demokrasi” inşa etmek olduğunu açıkça dile getirmiştir. ${ }^{6}$

\section{Fidezs'e karşı çözüm arayışları: İttifakların Gelişimi}

Fidesz'in 2012 tarihinde yapmış olduğu yeni anayasa ve bunu takiben girmiş oluğu otoriter patika Macar muhalefetini ama özellikle iktidardan düşmüş olan Sosyalistleri büyük bir endişeye sevk etti. Orban'ın sahip olduğu kitle desteğinin de farkında olan Sol, 2014 genel seçimlerine giderken fraksiyon farklarını bir yana bırakarak Fidesz karşısında güç birliğine gitmeyi tercih etti. Ama ittifaka gitmelerindeki en önemli neden sadece bu değildi. Fidesz anayasayı değiştirdiği gibi 2011 yılında da gücün hep elinde kalması niyetiyle seçim kanununda da bir dizi yeniliğe gitmişti.

Daha önceleri iki turlu karışık bir seçim sistemi benimseyen Macaristan bu değişiklikler ile seçimi tek tura indirdi ve vekil sayısını da düşürdü. Gözlemciler bu değişimin hedefinin çoğunlukçu seçim sonuçları olduğunu yani iktidar partisi kan kaybetse de iktidarın el değiştirmediği bir denklem olduğunu iddia etmişlerdir (Scheppele, 2014: 3) ${ }^{7}$. Aynı dönemde Fidesz seçmen kaydını zorlaştıran ve muhalif tabanın sandığa gitmesini caydıracak bir yasa da çıkardı (Verseck, 2012). Ancak muhalefetin şiddetli tepkisi ile karşılanan bu yasa anayasa mahkemesi tarafından veto edildi. Fidesz bunun haricinde 1. Dünya Savaşı sonrasında anavatan toprakları dışında kalan etnik Macarlara da vatandaşlık verdi ve yaklaşık 130 bin kişiyi seçmen listesine dahil etti. Fakat çifte vatandaşlık bu ülkelerde yasak olduğu için Macaristan Hükümeti seçmen listesine kayıt olanları gizli tutacağını açıkladı ve bu durum muhalefetin endişelerini

\footnotetext{
5 "OSCE pronounces Hungarian election free but unfair", https://budapestbeacon.com/osce-pronounceshungarian-election-free-but-unfair/

6 "Orban Says He Seeks to End Liberal Democracy in Hungary", https://www.bloomberg.com/news/articles/201407-28/orban-says-he-seeks-to-end-liberal-democracy-in-hungary

${ }^{7} 2014$ seçimleri bu eleştiriyi doğruladı, zira Fidesz bu seçimde 2010'da aldığı oydan 8 puan düşük (beş yüz bin daha az oy) almasına rağmen yapmış olduğu seçim reformu ile yine de parlamentonun 2/3'ünü kontrol edebildi.
} 
daha da artırdı (Scheppele, 2014: 18). Komşu ülkelerde yaşayan etnik Macarlar'ın seçmen listelerine kayıtları için her türlü kolaylığı sağlayan hükümet, Gurbetçi Macarlar'ın ise sürekli önlerine engeller çıkardı. Buna neden olarak ise eleştirmenler, Avrupa ülkelerinde yaşayan ve çalışan nüfusun, daha yüksek bir eğitim seviyesine sahip olmasını ve muhalefete oy verme eğilimlerinin yüksek olmasını göstermişlerdir (Scheppele, 2014: 21). Muhalefet de işte tüm bu manipülasyonlardan ve de seçim sisteminin çoğunlukçu bir görünüm kazanmasından dolayı seçime ittifak altında girmeyi tercih etmiştir (Verseck, 2012).

Seçim ittifakı arayışının öncüsü eski başbakanlardan Gordon Bajnai oldu. Eski bir sosyalist parti üyesi olan Bajnai, 2012 Ekim'indeki hükümet karşıtı protestolarında siyasete geri döneceğini söyledi ve Fidesz’e karşı geniş bir ittifakın kurulması gerektiği çağrısında bulundu: “Tek başımıza olursak kaybedebiliriz, fakat birlikte olursak zafer bizim olacaktır" (Feher, 2012). Bajnai ittifakın bileşenlerinin ise "umutlu solcular, hayal kırıklığına uğramış sağcılar, siyasetten yüz çevirmiş özgür düşünceliler ve de çevreciler” olması gerektiğini savundu ve değişimi arzulayan üç sivil toplum örgütü üzerinden, “Together 2014” (Birlikte 2014) adlı bir hareket başlattı. 2014 ifadesi hiç şüphesiz 2014'teki genel seçimleri ima ediyordu. Bajnai “Together 2014”ün, 1995 yılında İtalya'da Berlusconi'ye karşı kurulan The Olive Tree gibi bir çatı organizasyon olmasını bekliyordu. ${ }^{8}$ Ama önce Politics Can be Different (LMP), sonra da Macaristan Sosyalist Partisi (MSZP) bu öneriyi reddetti. Yine de LMP'nin bu teklifi reddetmesi partinin içini karıştırdı ve Gergely Karacsony önderliğindeki bir grup partiden ayrılarak Macaristan İçin Dialog (PM) adlı başka bir parti kurdu. PM sonrasında ise seçimlere girebilmek için partileşmek yolunu seçen Together 2014 ile seçim ittifakı kurduğunu duyurdu.

2014 yılına gelindiğinde ise Bajnai ittifak için yine Macaristan Sosyalist Partisi’nin kapısını çaldı ve 106 seçim bölgesinde tek aday ile seçime gidilmesini teklif etti. Bu teklif başta Sosyalist Parti olmak üzere diğer muhalefet partilerinden de kabul gördü ve böylece ittifak oluşturuldu. ${ }^{9}$ Beş partiden oluşan ve "Birlik" (unity) adını alan bu ittifakın bileşenleri şu şekildeydi: Macar Sosyalist Partisi (MSZP), Together 2014 (E14), Demokratik Koalisyon (DK), Macaristan İçin Dialog (PM) ve Macar Liberal Partisi (MLP). Ancak hiç de adil koşullar içinde gerçekleşmeyen seçim neticesinde ${ }^{10}$ Birlik $\% 25$ oy alarak seçimi ikinci sırada

\footnotetext{
8 "Hungarian Olive Tree Coalition in the making" https://www.budapost.eu/2011/10/hungarian-olive-treecoalition-in-the-making/

9 "A brief guide to Hungarian elections 2014", https://budapestbeacon.com/a-brief-guide-to-hungarian-elections$2014 /$

${ }^{10}$ Seçim rekabetinin hukuki ve finansal açıdan eşitsiz bir şekilde yürütülmesinin yanında kampanya sırasında da tarafların eşit olmadıkları tespiti yapılmıştır. Öyle ki, Fidesz seçim reklamlarının TV’lerden gösterilmesini
} 
bitirebildi. ${ }^{11}$ Cas Mudde Birlik'in bu başarısızlığının ardında kişisel ihtilafların olduğu kadar tüm liderlerin MSZP geçmişine sahip olmalarının da yattı̆̆ını savunmuştur. Bu yoruma göre 2008 krizinden sorumlu tutulan MSZP ve ondan çıkan muhalif figürler seçmenleri ikna edememiştir (Mudde, 2014).

Aynı yıl yapılan yerel seçimlerde ise her hangi bir ittifaka gidilmedi. Ancak sol ve liberal muhalefet, Budapeşte'de bir yıl önce kurulmuş bir muhafazakar parti olan Modern Macaristan Hareketi'nin (MoMa) adayını destekleme kararı aldı. Buna rağmen \%36 oy alarak ikinci sırada kaldilar.

2018 genel seçimlerine gidilirken de siyasal kamuoyunun en önemli gündemi ittifaktı. İttifak fikrinin en ateşli savunucusu ise genç bir aktivist olan Marton Gulyas'dı. Gulyas 2017 yılında, Fidesz rejimine karşı Country for All Movement (Tüm Hareketlerin/Görüşlerin Ülkesi) adlı bir hareket başlattı ve öncelikli hedefini de "seçim reformu" olarak belirledi. Bunun nedeni ise mevcut seçim kanunun, oy kaybetmesi halinde dahi Fidesz'in iktidardan inmemesi için düzenlenmiş olduğu tespitiydi. Hareketin taktiksel hedefi ise tek adaylı seçim bölgelerini kaldırarak, seçim sisteminin tamamını nispi oranlı hale getirmekti. Fidesz'in bunu kabul etmesi için ise STK'lar ve siyasal partiler ile birlikte "sivil itaatsizlik" eylemleri düzenlemeyi öngörmüşlerdi. Hareketin B planı ise mevcut seçim sistemi içinde Fidesz'i devirmek ve sonrasında adil bir seçim sistemi yaratmaktı. Marton Gulyas, bunu başarabilmenin yegane yolu olarak ise "seçim ittifaklarını" görüyordu ${ }^{12}$. Hareketin, seçim reformu ve seçim ittifakı çağrısına Jobbik hariç sekiz partiden destek geldi ve seçim ittifakı üzerine partiler görüşmeye başladı. Kasım ayında ise hareket 106 tane seçim bölgesinde Fidesz'in karşısına çıkarılacak en güçlü adayı belirlemek için kamuoyu araştırmaları yaptırdığını duyurdu. Bu adaylar hangi siyasi görüşten olursa olsun-hatta Jobbik üyesi de olabilirler- hareket onlara maddi ve manevi destekte bulunacağını da açıkladı. ${ }^{13}$ Hareketin bu projesi bazı bölgelerde sonuç verdi. Budapeşte'nin 1. Seçim bölgesi adaylarından olan ve Momentum Movement partisinin de lideri olan Fekete-

yasaklayıp sadece devlet televizyonundan sınırlı bir süre yayınlanmasına izin vermiştir. Açık alanlardaki reklamlarda da siyasal partilere önemli sınırlamalar getirilmiş̧tir. Ancak bu sınırlamalar sivil toplumun reklam vermesini engellemediği için 2014 kampanyasına Fidesz'e yakın olan STK'lar damgasını vurmuştur. Bu STK'lar da "Birlik" ittifakını hedef almış ve onlar aleyhine tüm billboardlara reklam vermişlerdir. "Birlik" ise seçmene çok sınırlı alanlarda erişebilmiştir. Bu konuda bkz. (Hakim, 2014).

11 "Hungary election: PM Viktor Orban declares victory", https://www.bbc.com/news/world-europe-26908404.

12 "Márton Gulyás: "There is no other option than a nonviolent civil disobedience movement" https://www.boell.de/en/2017/11/23/marton-gulyas-there-no-other-option-nonviolent-civil-disobediencemovement

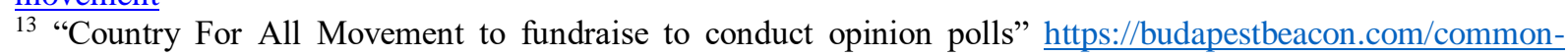
country-movement-fundraise-conduct-opinion-polls/ 
Györ, hareketin açıklamış olduğu ankette, MSZP'nin adayının, Fidesz'in karşısında kendisinden daha şanslı olduğu ortaya çıkınca adaylıktan çekildi. ${ }^{14}$ Kendisinden bir hafta önce de Together Partisi'nin lideri aynı bölgedeki adaylı̆̆ından, MSZP'nin adayı adına çekildiğini açıklamıştı. ${ }^{15}$ Ancak yine de adayları geri çekme ve tek aday ile Fidesz' in karşısına çıkma projesi tam anlamıyla başarıya ulaşamadı. Örneğin Momentum Movement başkanını adaylıktan çekmiş olmasına rağmen toplamda geri çektiği aday sayısı 10’u bulmadı. Bunun görünürdeki nedeni muhalefet partilerinin meydanı kötü şöhretli MSZP adaylarına bırakmak istememeleri ve Fidesz'in karşısında gerçek alternatifin kendileri olduğuna inanmalarıydı. Arka plandaki daha güçlü neden ise yeterli sayıda aday ile yarışmama neticesinde hazine yardımını kaybedecek olmalarıydı (80 üzerinde aday ile yarışan bir parti hazineden yaklaşık olarak 1.8 milyon dolar almaktadır). Muhalefet partileri bu kaynaktan mahrum olmamak için başka bir yol denediler; birçok bölgede aday gösterdiler, fakat tabanlarına “bölgenizde Fidesz’e karşı kim avantajlı durumdaysa, onu destekleyin" diye telkinde bulundular. ${ }^{16}$ Country For All Movement seçim günü de verdikleri ilan ile seçmenleri taktiksel oy vermeye davet etti ve 40-45 seçim bölgesini ittifak sayesinde Fidesz'den alabileceklerini ve böylece onları iktidardan düşürebileceklerini iddia etti. ${ }^{17}$

Tüm bu çabalara rağmen 2018 seçimlerinde resmi ittifaklar çok sınırlı kaldı; sol ve liberaller bir araya gelmedi ve sadece solun iki partisi arasında -MSZP ve PM- bir ittifak kurulabildi ve onlar da \%11 oy alarak, Jobbik'in ardından üçüncü sırada seçimi bitirebildiler. ${ }^{18}$ Ancak bu seçimde Başkent Budapeşte'nin \%60'ın üzerinde bir oy ile muhalefet partilerine yönelmesi, Fidesz için bir şok etkisi yarattı. ${ }^{19}$ Muhalefet de böylece Fidesz'in zayıf karnının Budapeşte ve genç seçmenler olduğunu görmüş oldu.

Ancak muhalefette heyecan uyandıran ve seçim ittifakının başarısına dair umutları artıran olay 45 bin nüfuslu küçük bir şehir olan Hódmezővásárhely’de yaşandı. Güney Doğu

\footnotetext{
14 "Momentum president Fekete-Győr withdraws from running in Budapest 1 st" https://budapestbeacon.com/momentum-president-fekete-gyor-withdraws-from-running-in-budapest-1st/

15 "It is unforgivable if left-wing opposition does not field a single candidate in each Budapest district" https://hungarianfreepress.com/2018/03/26/it-is-unforgivable-if-left-wing-opposition-does-not-field-a-singlecandidate-in-each-budapest-district/

16 "Momentum vows to keep majority of their candidates in the race" https://budapestbeacon.com/momentumvows-to-keep-majority-of-their-candidates-in-the-race/

17 “Country for All Movement: Orbán must go!" https://budapestbeacon.com/country-for-all-movement-orban$\underline{\text { must-go/ }}$

$\overline{18}$ "Hungary election: Viktor Orban claims landslide victory" https://www.dw.com/en/hungary-election-viktororban-claims-landslide-victory/a-43302609

19 "Viktor Orban victory in Hungary: German minister warns EU" https://www.bbc.com/news/world-europe$\underline{43697596}$
} 
Macaristan'daki bu küçük şehrin belediye başkanı görevi sırasında ölünce, 2018 Şubatı'nda şehir tekrar sandığa gitti. Seçime bağımsız aday olarak giren Peter Marki-Zay, muhalefet partilerinin de desteğini alarak 20 yılı aşkın süredir şehri yöneten Fidesz’i devirdi. Marki-Zay bu seçimde \%57,5 gibi bir oya ulaştı ve fakat daha da şaşırtıcı olan şey seçime katılımın yüksekliğiydi. 2014 yılında şehir sakinlerinin \%36sı sandığa giderken, bu ara seçimde katılım $\% 62,4$ 'e çıkmıştı. ${ }^{20}$ Bunun nedeni ise muhalefetin işbirliğinin başarıya olan inancı artırmasıydı. Seçilmesinden bir ay sonra ise Marki-Zay makamında şu açılamaları yapacaktı: "benim başarımın, 8 Nisan'daki genel seçimlerde tekrarlanmaması için bir neden göremiyorum (...) bu şehrin hikayesi, tüm ülkeye bir ders olabilir. Eğer muhalefet, diktatöre karşı ittifaka giderse bir umut doğacaktır ve umut olursa da, seçime katılım yükselecek ve Fidesz düşecektir” (Witte, 2018).

Görüldüğü üzere 2014 yılından itibaren Fidesz iktidarına karşı geliştirilen "seçim ittifakları" istenilen sonucu vermemiştir. Bu başarısızlığın ardından birçok neden gösterilebilir. Öncelikle Fidesz'in 2012 tarihinde ittifak riskini görerek seçim sistemini değiştirmesi, bu hamlenin gücünü zayıflatmıştır. İkinci olarak Fidesz'in 2013 yılından itibaren yıllık \%5 ekonomik büyüme yakalaması ve kişi başına düşen geliri 13bin dolardan, 16 bine çıkarması yine 2014'den

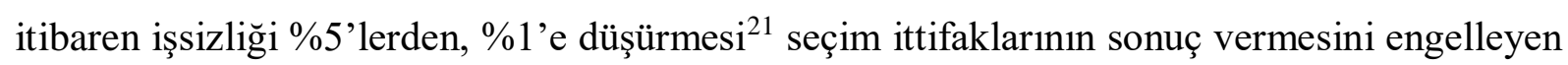
bir diğer etken olmuştur. Muhalefet partileri arasında geçmişten gelen ayrılıkların aşılması da henüz istenen raddeye gelmemiştir. Özellikle 8 yıl boyunca ülkeyi yöneten ve 2008 ekonomik krizinden sorumlu tutulan MZSP ile diğer muhalefet partileri bir araya gelmeme konusunda özen göstermektedirler. Ayrıca liderler ittifaka gidip, diğer parti liderlerinin gölgesinde kalmaktan hala imtina etmektedirler. Bu hassasiyeti gidermek için partiler üstü çatı organizasyonlar (Country For All Movement vd.) yaratma girişimlerinde bulunulmuş ve fakat bu da henüz istenen neticeyi verememiştir. Hazine yardımı meselesi de, ittifakların önünü tıkamaktadır. Zira bir parti yeterli sayıda seçim bölgesinde aday gösteremezse hazine yardımından mahrum olmaktadır. Aday göstermesine rağmen aday1 \%2'nin altında kalırsa ya da seçimden çekilirse bu yardımı geri ödemek zorunda kalmaktadır. Keza partiler de ulusal listeleri üzerinden $\% 1$ 'in altında kalırlarsa aynı şekilde geri ödeme yapmak durumundadırlar. ${ }^{22}$

\footnotetext{
20 “Fidesz bastion Hódmezővásárhely falls" https://budapestbeacon.com/fidesz-bastion-hodmezovasarhely-falls/ 21 "Hungary - Economic Indicators" https://tradingeconomics.com/hungary/indicators

22 "Limited Election Observation Mission: Hungary — Parliamentary Elections, 8 April 2018" OSCE https://www.osce.org/odihr/elections/hungary/377410?download=true
} 
Seçim İttifaklarının kotarılmasında bir diğer belirleyici etken de, bu taktiğin öğrenilme sürecidir. Zira literatürün de gösterdiği üzere seçim ittifakları basit birer matematiksel formül değildir, deneye yanıla öğrenilen, uygulama esnasında geliştirilen birer taktiktirler (Ong, 2018). $\mathrm{Bu}$ nedenle 2014 yılından itibaren denenmeye başlayan ittifakların başarısı istenen düzeye erişemese de, bazı seçim bölgelerinde sonuç verdiğini kabul etmek durumundayız. 2010 yılında seçim bölgeleri 176'yken, Fidesz bunun 173'ünü kazanmıştı. ${ }^{23} 2014$ genel seçimlerinde ise 106'ya inen seçim bölgelerinden 96'sını Fidesz kazand1. Bu seçimde Budapeşte'deki 18 seçim bölgesinden ise 10'unu elde etti. ${ }^{24} 2018$ genel seçimlerinde ise Fidesz ulusal düzeyde 91 bölgeyi kazanırken, Budapește'de 18 bölgeden sadece 6'sını kazanabildi ve ilk defa muhalefetin arkasında kaldı. ${ }^{25}$ Muhalefet cephesi bunu bir başarısızlık olarak okudu ve birçok istifa geldi. Muhalefetin tabanı ise başarısızlığı partilerin ittifaka yanaşmaması üzerinden yorumladı. ${ }^{26}$ 2019 yerel seçimlerine giderken muhalefet "ittifak" konusunda artık daha deneyimli ve istekliydi.

\section{2019 Yerel Seçimleri ve Seçim İttifakı}

Seçim ittifakının yerel seçimlerde başarı getireceği öngörüsü mayıs ayındaki Avrupa Parlamentosu seçimlerinden sonra dillendirilir olmuştu. Öyle ki, biraz da bu öngörü sayesinde ittifak görüşmelerinin yoğunlaştığını söyleyebiliriz. Avrupa Parlamentosu seçimleri muhalefetin oy oranını yükseltmese de, büyük şehirlerdeki oy potansiyelinin arttığını ayrıca seçmen davranışının da değişmeye başladığını gösterdi. Zira seçmen bu seçimde muhalefet adayları arasında dağılmayıp, en güçlü adaya yöneldi. En önemlisi aşırı sağ Jobbik'in seçmenleri ile sosyalist ve liberal partilerin seçmenleri bu seçimde Fidesz karşıtlı̆̆ üzerinden birbirlerinin partilerine yakınlaşma emareleri gösterdiler. Bu Fidesz'in bu zamana kadar başarılı bir şekilde uyguladığı sol ile sağ blokları bir araya getirmeme stratejisinin artık işe yaramadığını

23 "Election Watch Hungary", IRI http://www.iri.org/sites/default/files/Hungary\%20PostElection\%20Watch,\%20Apri1\%202010\%20Parliamentary\%20Elections.pdf

24 "How Fidesz won a two-thirds parliamentary majority with only $44.5 \%$ of the vote", https://budapestbeacon.com/how-fidesz-won-a-two-thirds-parliamentary-majority-with-only-44-5-of-the-vote/

25 "Viktor Orbán Wins Hungarian Parliamentary Elections", https://hungarytoday.hu/breaking-amid-high-voterturnout-viktor-orbans-ruling-fidesz-party-wins-hungarian-parliamentary-elections/

26 "Thousands rally against Viktor Orbán's election victory in Budapest", https://www.theguardian.com/world/2018/apr/14/thousands-rally-against-victor-orbans-election-victory-in-

$\underline{\text { budapest }}$ 
kanıtliyordu (Jambor, 2019). Mayıs ayındaki Avrupa Parlamentosu seçimlerini analiz eden Andras Jambor, muhalefetin her seçim bölgesinde tek aday ile yarışmak konusunda önemli bir deneyim kazandığını söyledikten sonra bazı projeksiyonlarda bulunuyordu. Buna göre muhalefet bu stratejiyi başarılı bir şekilde sürdürürse, ekim seçimlerinde şehirlerin yarısını kazanabilecekti (Jambor, 2019). Bu öngörü muhalefet tarafindan da paylaşıldı ve ilk elde Budapeşte, Szombathely, Dunaújváros, Szolnok, Pécs ve de Nyíregyháza gibi şehirlerde ayrıca Esztergom ve Komlótek gibi yerel birimlerde tek aday ile yarışma konusunda antlaşmaya vardılar. Bunun yanında Budapeşte'nin tüm ilçe belediyelerinde de tek aday çıkarma konusunda uzlaştılar. İlerleyen zamanlarda ise ittifakın çeperi genişledi ve 23 il belediyesinin hepsinde Fidesz'in karşısına tek aday ile çıkma kararı alındı.

Ekim ayında yapılan yerel seçimlere her ilde farklı ittifaklar ile giden muhalefet dokuz yıllık Fidesz iktidarı dönemindeki en büyük başarısını elde etti. Seçime giderken 23 şehirden sadece 3'üne sahip olan muhalefet, ittifaklar ile bu sayıyı 10'a çıkardı. Belediye meclis üyeliklerinde ise ittifak, başkanlığı alamadığı üç şehirde mecliste çoğunluğu elde etti. Katılım da 2014 yerel seçimlerinde \%44ken, bu seçimde \%49'a çıktı. Bu oran hem bir önceki seçime göre hem de ülkenin yerel seçim ortalamasına göre yüksektir. Bu nedenle seçime ittifakla gidilmesinin seçmenlerin muhalefetin başarılı olacağına dair inançlarını artırdığını söyleyebiliriz. Ayrıca başta Budapeşte olmak üzere ülkenin dört büyük sanayi ve ticaret şehrinden üçü de muhalefete geçmiştir.

Sosyalist ve liberal muhalefet hiçbir ilde birbirlerinin karşısına aday çıkarmamıştır. Aşırı sağcı Jobbik ise muhalefetin kazanmasının pek de mümkün olmadığı Debrecen'de, ittifak adayının karşısında aday çıkarmıştır; bunun dışındaki 22 ilin hiçbirinde Jobbik ya aday göstermemiş ya da ittifak adayını açıktan desteklemiş ve böylece oyların dağılmasına izin vermemiştir. Jobbik iki ilde ise (Dunaujvaros ve Eger) kendi adaylarını "bağımsız" olarak seçime sokmuş ve bu isimler sol-liberal ittifakın açıktan desteği ile Fidesz'den şehri almışlardır. $^{27}$

Ancak bazı illerde kimi kendi inisiyatifiyle kimi de Fidesz'in manipülasyon aracı olarak seçime giren ve oyların bölünmesine neden olan bağımsız adaylar olmuştur. Gyor ili bunun en çarpıcı örneğidir; eski bir dışişleri bakanı olan sosyalist Laszio Kovacs bu şehirde ittifaka rağmen adaylığını koymuş ve muhalefetin rahatlıkla kazanabileceği şehri Fidesz'e armağan

\footnotetext{
27 "Dunaújváros Will No Longer Finance The Oligarchs' Skulduggery" https://www.jobbik.com/dunaujvaros_will_no_longer_finance_the_oligarchs_skulduggery
} 
etmiştir. ${ }^{28}$ Muhalefet bu talihsizliğine karşın on ilde göstermiş olduğu başarı ile ülke yönetimine ortak olmuş ve Fidesz'in neden olduğu on yıllık "demokratik gerilemeye" set çekebilecek bir umut yaratmıştır. Bu başarının en büyük ayağı ise hiç şüphesiz ülke nüfusunun beşte birine ev sahipliği yapan, toplam zenginliğin de üçte birini üreten başkent Budapeşte'nin ittifakın adayı olan Karacsony tarafindan kazanılmasıdır.

\section{Budapeşte Adayı: Gergely Karacsony}

Gergely Karacsony'nin siyasi kariyeri 2009 y1lında yeni partilerden biri olan Politics Can Be Different' in (LMP) üyesi olması ile başladı. Bir yıl sonraki genel seçimlerde Budapeşte'den vekil olarak seçilerek, parlamentoya girdi ve partisinin grup lideri oldu. 2014 genel seçimlerinde LMP parti meclisinin, muhalefet partileri ile seçim ittifakına gidilmesini reddetmesi üzerine arkadaşları ile partiden ayrılarak, "Dialogue for Hungary" adlı yeni bir parti kurdu. 2014 yılında partinin eş başkanı olan Karacsony, aynı yıl yapılan yerel seçimlere Macar Sosyalist Partisi'nin, Demokratik Koalisyonun ve de Together 2014'un ortak adayı olarak girdi ve Budapeşte'ye bağlı Zuglo'nun belediye başkanı oldu. 2018 genel seçimlerine ise kendi partisi olan "Macaristan İçin Diyalog” (PM) ile "Macar Sosyalist Partisi'nin” (MSZP) ortak başbakan adayı olarak girdi ve üçüncü olarak seçimi bitirdi.

2019 Ekim'inde ise altı partinin ortak adayı olarak Budapeşte Belediye Başkanlığı için yarıştı ve iktidardaki Fidesz Partisi'nin 9 yıllık Belediye Başkanı olan Istvan Tarlos'u koltuğundan etti. Aşırı Sağcı Jobbik Partisi de Karacsony’i desteklememekle birlikte aday çıkarmayarak, Tarlos’un karşısına tek alternatif olarak çıkmasına vesile oldu ve \%50,8'lik seçim zaferinde önemli bir etkisi oldu.

Karacsony'nin kişiliği bu başarının elde edilmesinde çok önemli bir etkiye sahiptir. Siyasi kariyerinin büyük bir kısmını Fidesz yönetimi altında geçiren politikacı sürekli ittifakı düşünmüştür. LMP'den ittifaka yanaşmadığı için ayrılan Karacsony, muhalefetin bir kısmının başbakan adayı olarak girdiği 2018 genel seçimlerinde de "ittifak" konusunda sıklıkla kendi partilileri ile karşı karşıya gelmiştir. O dönemde en ihtilaflı konu aşırı sağcı Jobbik Partisi ile ilişkilerin nasıl olacağı üzerineydi ve sosyalistler Jobbik'le yan yana gelmemeyi çok önemsiyordu. Karacsony ise Orban’ı yerinden etmeyi sağlayacaksa her türlü yakınlaşmaya

\footnotetext{
28 "Local elections - Results in major Hungarian cities" https://dailynewshungary.com/local-elections-results-in-major-hungarian-cities/
} 
sıcak bakıyor ve şöyle diyordu: "Herkesle işbirliği yapmak zorundayız, şeytanla bile" (ak. Witte, 2018).

\section{Muhalefetin Ortak Adayı Olma Süreci:}

2019'un Haziran ayında muhalefet, Budapeşte Belediye Başkanlığı için ortak aday belirlemeyi kararlaştırdı. Fakat bu adayın nasıl seçileceği konusunda Macaristan tarihinde görülmemiş bir yolu tercih ederek kendi aralarında "ön seçim” yapmayı tercih ettiler. 2014 yerel seçimlerinde de özellikle sol muhalefet gayri resmi bir ittifaka giderek eski bir ekonomi bakanını, Belediye Başkanı Tarlos’un karşısına çıkarmıştı. Ancak bu ittifak bir başarı getirmemişti. Zira sol dışındaki partiler bu ittifaka yanaşmamışlar ve neticede Fidesz'in adayının karşısına muhalefet dört aday ile çıkarak başarısız olmuştu. 2019 yılının başında ise sol muhalefet partileri, sağ muhalefet ile iki turlu bir ön seçim sonucunda ortak adayı belirleme hususunda anlaştılar. Buna göre sol muhalefet şubatta kendi arasında bir ön seçim yaparak adayını belirledikten sonra haziranda merkez ve sağ partilerin adayı ile tekrar bir ön seçim yapılarak "ortak aday" belirlenecekti. Şubat ayında MSZP ile PM ön seçim yaparak Karacsony'i solun adayı olarak belirledi. Bu ön seçime MSZP, PM, Democratic Coalition (DK) ve Solidarity Movement adlı sol partiler girdi. 35 bin seçmenin \%80'inin oylarını alarak ön seçimden başarı ile çıkan Karacsony zafer konuşmasında hedeflerinin Budapeşte'yi Fidesz'in “Koloni Valisi’nden” alıp, sakinlerine geri vermek olduğunu söyledi. Ön seçim neticesinde Fidesz ve onun kutuplaştırıcı politikaları dışında kimsenin kaybetmediğini belirten politikacı, yaptıkları şeyin muhalefete bir önder ve politika aramak olmadığını aksine Budapeşte halkının tümüne, halkçı bir program aramak olduğunu iddia etti. Muhalefet partilerinin liderleri de ön seçimin ardından yaptıkları konuşmalarda Karacsony’nin arkasında olduklarını güçlü bir şekilde dile getirdiler. Budapeşte'yi yöneten Tarlos, Orban'ın atadığı bir genel valiyken, Karacsony’nin bizzat Budapeşteli seçmenler tarafından seçildiğini ve bunun demokratik güçlerin bir başarısı olduğunu savundular. İktidarın sözcüleri ise katılımın düşüklüğü üzerinden, ön seçimin fiyasko ile sonuçlandığını ve muhalefetin kendi tabanını bile sandığa götüremediğini iddia ettiler. ${ }^{29}$

\footnotetext{
29 "Karácsony Wins Left-wing Mayoral Preselection", https://hungarytoday.hu/karacsony-wins-left-wing-
} mayoral-preselection/. 
Haziran ayına geldiğimizde ise Karacsony, liberal-merkez partilerin (Democratic Coalition ve Momentum) adayları ile ön seçime girdi ve yaklaşık 70 bin kişinin elektronik ortamda ya da fiili bir şekilde katıldığı seçimde \%48,9 oy alarak, altı muhalefet partisinin ortak adayı haline geldi. Radikal-săg parti Jobbik bu ittifakın içinde yer almasa da, muhalefetin ön seçiminden çıkan Karacsony’e karşı aday çıkarmayacağını açıkladı ${ }^{30}$. Jobbik'in bu kararına rağmen iki bağımsız aday seçime girme kararı aldı. Şubat ayında muhalefetin tüm bileşenleri ön seçimin sonucuna saygı duyacaklarını açıklamış olsalar dahi sosyal medya üzerinden büyük bir popülerlik kazanan yayıncı ve TV sunucusu Robert Puzser Nisan ayında ön seçimi kabul etmediğini ve muhakkak seçimlere katılacağını duyurdu. Bu dönemde öne çıkan yorumlarda Puzser'in bu kararının bir spoiler effect yaratacağı ve Karacsony'e gidecek oyları bölerek Tarlos’un kazanmasına neden olacağı iddiaları öne çıkıyordu (Gaal, 2019).

Ön seçimin yapıldığı hafta muhalefeti ittifakın başarısına inandıran bir de büyük olay gerçekleşti. İstanbul'da yenilenen belediye başkanlığı seçimini muhalefet ittifakının adayı olan Ekrem İmamoğlu kazandı ve 17 yıldır Türkiye'yi ve İstanbul'u yöneten Adalet ve Kalkınma Partisi'ne tarihinin en büyük seçim yenilgisini yaşattı. Bu başarı Macaristan muhalefetinde de büyük bir heyecan uyandırdı ve seçim ittifakının isabetliliğine olan inancı artırdı. Öyle ki, eski başbakanlardan ve Demokratik Koalisyon Partisi'nin de lideri olan Ferenc Gyurcsany şunları söylemekteydi: "Başkenti kazanan, ülkeyi kazanır (...) herkes ön seçimi kazanan adayı desteklemelidir. Ve biz de öyle yapacağız. Muhalefetin tek bir belediye başkanı adayı olacaktır” (Dunai, 2019). Karacsony ön seçim sonrasında yaptığı konuşmada da bu umudu paylaşıyordu: "Partilerin işbirliğine gidebilmiş olması bize Macaristan'da hala bir tartışma ve demokrasi kültürü olduğunu gösteriyor (...) Bu şehir Fidesz'den farklı bir şey istiyor” dedi (Dunai, 2019).

\section{Kampanya ve Seçim:}

Ön seçim sürecinde kampanyasını başlatan Karacsony'nin iki noktada hassasiyet gösterdiğini söyleyebiliriz. Öncelikle 2000’li yıllarda hükümet olan ancak 2008 ekonomik krizi karşısında tutunamayan ve halk nezdinde popülaritesi düşmekte olan solun birinci partisi MSZP'den kendini olabildiğince ayırmaya çalıştı. Öyle ki, gözlemciler Karacsony’nin

\footnotetext{
30 “Jobbik Accepts Outcome of Budapest Local Election Opposition Preselection" https://hungarytoday.hu/jobbikbudapest-opposition-preselection/
} 
kampanyasını “de-MSZP”leştirdiğini iddia ettiler. ${ }^{31}$ İkinci olarak ise kendisini partiler üstü bir aday olarak göstermeyi denedi ve bu amaçla kampanya boyunca bir partiye yakınlık olarak yorumlanacak hiçbir logo ya da sembol kullanmadı. Karacsony kampanya süresince aşırı sağcı Jobbik'in aday göstermemesi için de dolaylı olarak uğraştı ve bu noktada zaman zaman ağır eleştiriler de aldı. Jobbik ile karşı karşıya gelmemeye çalışan politikacı, bu partinin vekillerinden birinin yaptığı "anti semitik” çıkışı eleştiremediği gibi normalleştirmeye de çalışt1. ${ }^{32}$

Karacsony, Ağustos ayında ise İstanbul'a geldi ve 25 y1ldır muhafazakarların elinde bulunan İstanbul'u "seçim ittifakı" ile alan Ekrem İmamoğlu ile bir görüşme gerçekleştirdi. Seçim stratejisi konusunda görüşlerine başvurduğu İmamoğlu'na “Budapeşte için de ümit kaynağı oldunuz" dedi. ${ }^{33}$ Bu dönemde basına yaptığı açıklamalarda sıklıkla İstanbul ve Varşova örneklerini hatırlatan politikacı, bu şehirlerin muhafazakar iktidarların, ilerici şehirleri olduğunu ve buralardaki dönüşümün tüm ülke için bir değişim fırsatı yarattığını belirtti. Karacsony aynı konuşmada ekibinin Varşova Belediye Başkanı ile kampanya bağlamında işbirliği yaptığını da dile getirdi. ${ }^{34}$ Bunların yanında kampanya süresince yapılacak olan seçimin basit bir yerel seçim olmadığını da sıklıkla tekrar etti ve yerel yönetimlerde elde edilecek olan başarının, otoriter hükümetin gücünü dengelemek için çok önemli bir adım olacağını iddia ederek ${ }^{35}$ “Başkenti almak, Orban'ın rejiminde bir çatlak açacaktır” ifadesini kullandı. Bu hedefle başkan olduğu takdirde, şehirdeki Fidesz kaynaklı tüm projelere son vereceğini, Fidesz'in şehirde ücretsiz dağıttığı kent gazetesini ilga edip, tarafsız bir gazeteyi halkla buluşturacağını ve "Budapeşte Anayasası" için hazırlıklara başlayacağını da belirtti. ${ }^{36}$ Kampanyanın ana hedefi Fidesz'in illiberal rejiminden çıkış olarak belirlense de, Karacsony bunun haricinde de bir dizi aktüel vaatlerde bulundu. Buna göre kazandığg takdirde düşük gelirli vatandaşların sosyal güvencesini geliştirecek, evsizler için daha fazla kaynak ayıracak, toplu

\footnotetext{
31 “Gergely Karácsony’s Success And The Collapse Of Mszp” https://hungarianspectrum.org/2019/06/29/gergelykaracsonys-success-and-the-collapse-of-mszp/

32 "Liberal opposition leader: it's not Nazism if someone makes a list of Jews", http://abouthungary.hu/blog/videoliberal-opposition-leader-its-not-nazism-if-someone-makes-a-list-of-jews/

33 "Karacsony'den İmamoğlu'na: "Budapeşte İçin De Ümit Kaynağı Oldunuz" https://www.ibb.istanbul/News/Detail/35729

34 "Orban's foes reach rare unity in bid to win control of Budapest" https://www.ft.com/content/2ae13dca-e930$\underline{11 \mathrm{e} 9-\mathrm{a} 240-3 \mathrm{~b} 065 \mathrm{ef} 5 \mathrm{fc} 55}$

35 "Karácsony: Only Local Council Autonomy 'Can Counterbalance Govt Powers"” https://hungarytoday.hu/karacsony-orban-government-authority-local-elections/

36 "Local elections - Karácsony promises to free Budapest from NER 'captivity', https://dailynewshungary.com/local-elections-karacsony-promises-to-free-budapest-from-ner-captivity/
} 
taşımayı yeniden düzenleyecek ve en önemlisi yeşil alanları geliştirerek, hava kirliliğini azaltacakt $1 .^{37}$

$\mathrm{Bu}$ süre zarfında iktidar da boş durmadı ve ittifakı dağıtmak amacıyla Karacsony’nin montajlanmış ses kayıtlarını sosyal medyaya servis etti. Bu kayıtlarda Karacsony’nin, Macar Sosyalist Partisi'ne dönük eleştirileri bulunuyordu. Ancak siyasetçi sesin kendisine ait olduğunu ve bağlamı dışında kurgulandığını iddia etti ve yapılan manipülasyonun "gizli servis" yöntemi olduğunu söyleyerek, Fidesz'i işaret etti. ${ }^{38}$ Fidesz ayrıca Budapeşte seçmeninin muhalefete kaymasına mani olmak için manipülasyonlar da yaptı. Eylül ayında Başbakanlık sözcüsü Gergely Gulyas, bir basın toplantısında bir yıl kadar önce Orban ile mevcut belediye başkanı arasında Budapeşte'nin finansal ve idari açıdan güçlendirilmesi için 15 maddelik bir antlaşma yapıldığını açıkladı. Ancak bu antlaşmanın makamlar arasında değil, kişiler arasında gerçekleştirildiğini ve Fidesz dışında bir partinin başkanlığı kazanması durumunda geçerliliğini yitireceğini de ekledi. Karacsony ise açıklamanın Budapeşte halkına dönük bir şantaj olduğunu iddia ederek, Seçim Kurulu'na Gulyas'ı şikayet etti ve ayrıca istifasını istedi. ${ }^{39}$

13 Ekim günü yapılan seçime Budapeşte halk1 \%51lik bir katılım gösterdi ki bu hem geçmiş oranlarla hem de ulusal katılımla mukayese edildiğinde oldukça yüksek bir katılımdı ve sandıktan \%50’ye \%44 gibi bir oranla Karacsony galip çıktı. Başarı sadece başkanlık makamı ile sınırlı değildi. İttifak Budapeşte'nin ilçe belediyelerinde de sonuç verdi ve yirmi üç ilçe belediyesinden sadece yedisi Fidesz'in kontrolünde kalırken, on dördü resmen muhalefet ittifakına geçti (iki bağımsız belediye başkanının, Orban'a yakın oldukları iddia edilmekteydi). Öyle ki, belediye meclisinde de muhalefet çoğunluğu eline geçirdi. Karacsony seçim zaferini şu cümleler ile ilan etti: “Bu Yeşil ve Özgür Budapeşte’nin, iktidarı elinde tutanlara karşı halkın, nefrete karşı sevgi ve işbirliğinin, yalanlara karşı gerçeklerin zaferidir”. 40 Yeni Belediye Başkanı bir gazeteye verdiği demeçte de esas başarısının belediye kazanmak değil, ülkenin demokratikleşebileceğine dair kitlelere bir umut aşılamak olduğunu söyledi: "seçimin temel mesajı Fidesz'in sonsuza dek iktidarda kalamayacağıdır. Bu başarı ile psikolojik bir bariyer kırılmış oldu”. Aynı konuşmada Karacsony seçim ittifakının başarısına artık daha fazla kişinin

\footnotetext{
37 "New Budapest mayor Gergely Karácsony - consensus builder with a cause", https://www.themayor.eu/en/newbudapest-mayor-gergely-karacsony-consensus-builder-with-a-cause

38 "Leaked Audio of Mayoral Candidate On Threats and Inner Fights, Stirs Controversy", https://hungarytoday.hu/leaked-audio-of-mayoral-candidate-on-threats-and-inner-fights-stirs-controversy/

39 "Budapest Mayoral Candidate Karácsony Calls for the Resignation of Minister" https://hungarytoday.hu/budapest-mayoral-candidate-karacsony-calls-for-the-resignation-of-minister/

40 "Karácsony wins mayoral race, opposition regains Budapest" https://bbj.hu/politics/karacsony-wins-mayoralrace-opposition-regains-budapest_172625
} 
inandığını ve bu inancın 2022 genel seçimlerinde de demokratik bir sonuç vereceğini iddia etti. 41

\section{Sonuç}

Genel olarak melez rejimlerden, özel bir tür olarak da rekabetçi otoriter rejimlerden çıkışta "seçim ittifakları" stratejisi giderek yaygınlaşmakta ve zaman zaman da başarı kazanmaktadır. Buna paralel bir diğer gelişme de, popülist-otoriter rejimlerde başkentlerin demokratik ve özgürlükçü siyasi hareketlerin eline geçmesidir. Çekya, Polonya, Slovakya ve Macaristan'da bu değişim gözlemlenirken, Macaristan ve Türkiye'de ${ }^{42}$ de bu değişimde "seçim ittifakları" başarı getirmiştir. Yerel seçimlerdeki başarının, ulusal hükümet için verilen mücadelede bir kaldıraç etkisine sahip olması özellikle baskıcı rejim deneyimlerinde ön plana çıkmaktadır. Meksika ve Brezilya'nın 1990'lardaki deneyimi sık sık bu iddiaya kanıt olarak sunulmaktadır. Yerel hükümet için verilecek mücadelenin öncelikle strateji boyutu, ulusal hükümet rekabetine bir model sağlayabilmektedir. İkinci olarak muhalefet bu alanı tutarak, iktidarın güç alanını daraltmakta ve de onun tasarruflarını daha iyi denetleyebilmektedir. Üçüncü olarak ise muhalefetin yerel yönetimlerdeki başarılı performansı, ulusal seçimlerdeki kanaati de değiştirebilecek bir etkiye sahiptir. Son olarak muhalefetin yerel yönetimlerdeki varlığ bürokrasi ve yargı olmak üzere, medya ve sermaye çevresinde de bir nötralizasyona neden olmakta ve uzun vadede rekabet alanının daha adil bir dengeye kavuşmasına imkan sunmaktadır.

Seçim ittifakları da birçok açıdan iktidarın manipülasyon imkanlarını daraltmakta, seçmenleri başarıya ikna edip, katılımı artırmakta ve de bürokrasinin nötralizasyonunu kolaylaştırmaktadır. Bu nedenle de melez rejimlerden çıkışta en etkili siyasal strateji olarak görülmektedir. Macaristan yerel seçimlerindeki başarı da birçok açıdan bu hipotezleri doğrulayacak potansiyele sahiptir. On yıllık popülist otoriter Fidesz iktidarı, sahip olduğu yasama gücünü istismar ederek rekabet alanını sürekli kendi lehine bozmaktadır ve muhalefetin manevra alanı her geçen gün daralmaktadır. Bu nedenle yerel seçimlerde 10 şehrin kazanılmış olması bu kuşatmanın yarılması açısından hayati bir önemi haizdir. Elbette ki, bu bir genel

\footnotetext{
41 "Budapest's new mayor rides into battle with Viktor Orban" https://www.ft.com/content/8e7e130a-f0d1-11e9ad1e-4367d8281195

${ }^{42}$ Seçim ittifaklarının, Türkiye'nin 2019 yerel seçimlerinde nasıl inşa edildiğini ve nasıl bir başarı elde ettiğini başka bir çalışmamızda göstermiştir. Ayrıntılı bilgi için Bkz. Oğuz, M. C. Seçimlerin, Demokratikleşme Sürecine Etkileri: Seçim İttifakları Ve Türkiye Üzerine Bir Tartışma. Memleket, Siyaset Ve Yönetim, 14-31, S.93-128.
} 
seçim değildir ve iktidar el değiştirmemiştir. Fakat sahada güç vektörleri yoğunlaşmış ve iktidarın karşısına bir blok yerleşmiştir. AB üyesi olan Macaristan'ın bir avantajı da, birçok AB fonunun doğrudan kentler tarafından kullanılabilmesi ve kentlerin sahip olduğu özerkliktir. $\mathrm{Bu}$ da Fidesz' in finansal ve idari baskısının azalacağına işaret etmektedir. Bunun yanında başkent Budapeşte'nin kazanılmış olması da hem Fidesz'in kontrol alanının daralması açısından, hem de ulusal seçim rekabetinde sağlayacağı avantaj açısından önemlidir. Zira Budapeşte ülke nüfusunun üçte birine ve ekonominin yüzde kırkına ev sahipliği yapmaktadır. Karacsony bunun yanında Visegrad ülkelerinin başkent belediye başkanları ile de "özgür şehirler sözleşmesi”" yapmıştır. $\mathrm{Bu}$ antlaşma ile dört belediye başkanı popülist otoriter hükümetlerine karşı bir dayanışma niyeti ortaya koymuşlardır. Tüm bunlar bir arada düşünüldüğünde, seçim ittifakı ile elde edilen yerel seçim başarısının Macaristan'da “özgürleştirici sonuçlar” verdiğini şimdiden söyleyebiliriz.

Seçimin ürettiği ve üreteceği bu özgürleştirici sonuçlar haricinde, muhalefete kazandırdığı bir diğer avantaj da, strateji deneyimidir. İlgili literatürün de gösterdiği üzere seçim ittifakları matematiksel bir formülasyona dayanmamaktadır. Her bir ittifak deneyimi bir öncekinin noksanlarını gidererek ilerlemektedir. 2014 yılından beri çeşitli ittifak senaryoları icra eden Macar muhalefeti ilk defa bu seçimde olumlu bir sonuç almıştır. Bu deneyimin artıları ve eksileri 2022 genel seçim stratejisi oluşturulurken mutlaka dikkate alınacaktır. Özgürleştirici seçim çıktıları, bu stratejik deneyimle birleştiğinde Macaristan'ın tekrar demokratikleşme rotasına gireceğini düşünebiliriz. 


\section{Kaynakça:}

Bajomi-Lázár, P. (2013). The party colonisation of the media: The case of Hungary. East European Politics and Societies, 27(1), 69-89.

Bajomi-Lazar, P. (2017). Particularistic and universalistic media policies: Inequalities in the media in Hungary. Javnost-The Public, 24(2), 162-172.

Bátorfy, A., \& Urbán, Á. (2019). State advertising as an instrument of transformation of the media market in Hungary. East European Politics, 1-22.

Biro-Nagy, A. (2017). Illiberal democracy in Hungary: the social background and practical steps of building an illiberal state. Illiberal Democracies in the EU: the Visegrad Group and the Risk of Disintegration, Barcelona: Color Marfil, SL.

Bogaards, M. (2009). How to classify hybrid regimes? Defective democracy and electoral authoritarianism. Democratization, 16(2), 399-423.

Bozóki, A., \& Hegedűs, D. (2018). An externally constrained hybrid regime: Hungary in the European Union. Democratization, 25(7), 1173-1189.

Bunce, V. J., \& Wolchik, S. L. (2010). Defeating dictators: Electoral change and stability in competitive authoritarian regimes. World politics, 62(1), 43-86.

Buzogány, A. (2017). Illiberal Democracy In Hungary: Authoritarian Diffusion Or Domestic Causation?. Democratization, 24(7), 1307-1325.

Carothers, T. (2002). The end of the transition paradigm. Journal of democracy, 13(1), 5-21.

Diamond, L. (2002). Elections without democracy: Thinking about hybrid regimes. Journal of democracy, 13(2), 21-35

Donno, D. (2013). Elections and democratization in authoritarian regimes. American Journal of Political Science, 57(3), 703-716.

Diamond, L., Plattner, M. F., \& Walker, C. (Eds.). (2016). Authoritarianism goes global: The challenge to democracy. JHU Press.

Dunai, Marton (2019). Liberal wins Budapest primary to face Orban's Fidesz in mayoral election. Reuters. https://af.reuters.com/article/worldNews/idAFKCN1TR2XP (Erişim, 11/2019). 
Feher, Margit (2012). Hungarian Newcomer Instantly Becomes Most Popular Opposition Force. The Wall Street Journal.

https://blogs.wsj.com/emergingeurope/2012/11/08/hungarian-newcomer-instantlybecomes-most-popular-opposition-force/ (Erişim, 11/2019).

Fox, J. (1994). Latin America's emerging local politics. Journal of Democracy, 5(2), 105-116.

Gaal, Bence (2019). Karácsony wins opposition primary for Budapest mayor. Budapest

Business Journal. https://bbj.hu/politics/karacsony-wins-opposition-primary-forbudapest-mayor_167666 (Erişim, 11/2019).

Hakim, Danny (2014). How Did Hungary's Election Become a Circus?. The New York Times. https://www.nytimes.com/2014/03/02/sunday-review/how-did-hungarys-electionbecome-a-circus.html (Erişim, 11/2019).

Howard, M. M., \& Roessler, P. G. (2006). Liberalizing electoral outcomes in competitive authoritarian regimes. American Journal of Political Science, 50(2), 365-381.

Jambor, Andras (2019). Transforming the opposition in Hungary after the EP elections.

Heinrich Böll Stiftung-The Green Political Foundation.

https://www.boell.de/en/2019/07/03/transforming-opposition-hungary-after-epelections (Erişim, 11/2019).

Landau, D. (2013). Abusive constitutionalism. UCDL Rev., 47, 189.

Levitsky, S., \& Way, L. A. (2010). Competitive authoritarianism: Hybrid regimes after the Cold War. Cambridge University Press.

Magyar, B. (2016). Post-communist mafia state. Central European University Press.

Martin, J. P. (2017). Continuity or disruption? Changing elites and the emergence of cronyism after the great recession-The case of Hungary. Corvinus Journal of Sociology and Social Policy, 8(3), 255-281.

Mudde, Cas (2014). The 2014 Hungarian parliamentary elections, or how to craft a constitutional majority. The Washington Post.

https://www.washingtonpost.com/news/monkey-cage/wp/2014/04/14/the-2014hungarian-parliamentary-elections-or-how-to-craft-a-constitutional-majority/ (Erişim, 11/2019). 
Oğuz, M. C. (2019). Seçimlerin, Demokratikleşme Sürecine Etkileri: Seçim İttifakları Ve Türkiye Üzerine Bir Tartışma. Memleket, Siyaset Ve Yönetim, 14-31, S.93-128.

Ong, E. (2018). Opposing Power Over Time: Learning to Build Opposition Coalitions in Electoral Autocracies. Prepared for SEAREG-in-Asia 2018 at Yale-Nus.

Rogers, S. (2019). Fidesz, the state-subsumption of domestic business and the emergence of prebendalism: capitalist development in an 'illiberal'setting. Post-Communist Economies, 1-16.

Scheppele, K. L. (2013). 1. Title: The Rule of Law and the Frankenstate: Why Governance Checklists Do Not Work. Governance, 26(4).

Scheppele, K. L. (2014). Hungary: An Election in Question.

http://digitalcommons.law.umaryland.edu/cgi/viewcontent.cgi?article=1174\&context= schmooze_papers (Erişim, 11/2019).

Tóth, I. J., \& Hajdu, M. (2016). Competitive Intensity and Corruption Risks in the Hungarian Public Procurement 2009-2015. The Corruption Research Center: Budapest, Hungary.

Tóth, I. J., \& Hajdu, M. (2018). How does the Kleptocratic State Work in Hungary?. Corruption Research Center, Budapest.

Van de Walle, N. (2006). Tipping games: When do opposition parties coalesce?. Electoral authoritarianism: The dynamics of unfree competition, 77-94.

Verseck, Keno (2012). Orbán Cements His Power With New Voting Law. Spigel Online. https://www.spiegel.de/international/europe/hungarian-parliament-amends-electionlaw-a-864349.html

Witte, Griff (2018). To stop Viktor Orban, Hungary's opposition parties need to team up. But can they?. The Washington Post. https://www.washingtonpost.com/world/europe/tostop-viktor-orban-hungarys-opposition-parties-need-to-team-up-but-canthey/2018/03/20/e226f04c-2604-11e8-a227-fd2b009466bc_story.html (Erişim, 11/2019). 